EXTRAORDINARY JUSTICE 



\section{Extraordinary Justice}

LAW, POLITICS, AND THE KHMER ROUGE TRIBUNALS

\section{Craig Etcheson}

Columbia University Press

New York 


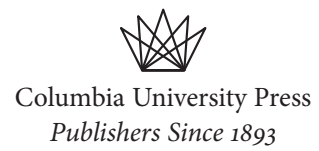

New York Chichester, West Sussex

cup.columbia.edu

Copyright $\left({ }_{0} 2020\right.$ Columbia University Press

All rights reserved

Library of Congress Cataloging-in-Publication Data

Names: Etcheson, Craig, 1955- author.

Title: Extraordinary justice : law, politics, and the Khmer Rouge tribunals / Craig Etcheson.

Description: New York : Columbia University Press, 2019. |

Includes bibliographical references and index.

Identifiers: LCCN 2019015221 (print) | LCCN 2019018061 (ebook) | ISBN 9780231550727

(electronic) | ISBN 9780231194242 (cloth : alk. paper) | ISBN 9780231194259 (pbk.)

Subjects: LCSH: Extraordinary Chambers in the Courts of Cambodia. |

Trials (Crimes against humanity)-Cambodia.

Classification: LCC KZ1208.C36 (ebook) | LCC KZ1208.C36 E83 2019 (print) |

DDC 341.6/90268-dc23

LC record available at https://lccn.loc.gov/2019015221

Columbia University Press books are printed on permanent and durable acid-free paper.

Printed in the United States of America

Cover image: (๑) Nic Dunlop/panos pictures

Cover design: Lisa Hamm 